\title{
Changes in the sea-ice brine community during the spring-summer transition, McMurdo Sound, Antarctica. I. Photosynthetic protists
}

\author{
Diane K. Stoecker ${ }^{1}$, Kurt R. Buck ${ }^{2}$, Mary Putt ${ }^{3}$ \\ ${ }^{1}$ Horn Point Environmental Laboratory, PO Box 775, Cambridge, Maryland 21613, USA \\ ${ }^{2}$ Monterey Bay Aquarium Research Institute, 160 Central Avenue, Pacific Grove, California 93950, USA \\ ${ }^{3}$ Department of Oceanography, Old Dominion University, Norfolk, Virginia 23529, USA
}

\begin{abstract}
During the austral spring, a characteristic microbial community develops in the subsurface brine pockets and channels of the annual land-fast sea-ice in McMurdo Sound. This community is distinct from the diatom-dominated community that develops in the channels at the base of the seaice, at the seawater/ice interface, and in the platelet layer The photosynthetic biomass in the brine pockets is dominated by athecate dinoflagellates. Chrysophyte statocysts isometimes known as archaeomonads) and $<5 \mu \mathrm{m}$ photosynthetic flagellates are also characteristically found in this assemblage. In December, chlorophyll a content and biomass peak, and photosynthetic gymnodinioid dinoflagellates can reach densities of over $10^{3} \mathrm{ml}^{-1}$ of brine. The photosynthetic dinoflagellates form cysts (hypnozygotes) during late December and early January, and chrysophyte statocysts also become abundant. During austral summer, total autotrophic biomass in the upper ice brine decreases due to dilution by melt water, flushing of brine into the water column, and grazing. By late summer, the annual sea-ice in McMurdo Sound has broken out. The yearly decay and retreat of sea-ice introduces a characteristic set of brine protists and their cysts into McMurdo Sound.
\end{abstract}

\section{INTRODUCTION}

During the austral winter, annual sea-ice covers about 17 million $\mathrm{km}^{2}$ of ocean surrounding the Antartica continent, an area larger than the continent itself (Zwally et al. 1983). Sea-ice exerts an important influence on ocean circulation, weather and climate as well as being a crucial habitat for Antarctic biota (reviewed in Horner 1985, Maykut 1985, Garrison et al. 1986, Vincent 1988, Glasby 1990, Garrison 1991). The microbial communities associated with sea ice are important in several respects. Absorption of heat by sea-ice microbes is thought to influence ice melting, porosity and ice strength and hence break-up of the annual ice (Meguro 1962, Buynitskiy 1968, McConville \& Wetherbee 1983, Maykut 1985, Eicken et al. 1991). Production by sea-ice protists contributes to food webs in the plankton and in the benthos (Knox 1990, Matsuda et al, 1990, Garrison 1991).

Sea-ice varies in its formation, structure and biota (reviewed in Garrison 1991). In the pack-ice of the
Weddell Sea, microbial communities are usually internal or concentrated in a surface or subsurface brine layer (Garrison \& Buck 1989, 1991). In land-fast ice, microbial communities are often most conspicuous at or near the base of the sea-ice (Hoshiai 1972, Palmisano \& Sullivan 1983, McConville \& Wetherbee 1983, Sasaki \& Watanabe 1984). However, in some coastal areas of Antarctica, microbial communities occur in surface pools, in subsurface brine pockets or in internal bands in the land-fast ice (Meguro 1962, McConville \& Wetherbee 1983, Watanabe et al. 1990). Diatoms are reported to dominate the biomass in both land-fast (reviewed in Horner 1985) and pack ice (Garrison \& Buck 1989, 1991).

Recently, we reported a dinoflagellate-dominated assemblage in the upper land-fast ice from McMurdo Sound (Stoecker et al. 1990, 1991). This assemblage inhabits brine channels and pockets that extend from about $10 \mathrm{~cm}$ below the ice surface into the congelation ice. This brine community is distinct from the diatomdominated microbial communities at the base of the 
sea-ice in McMurdo Sound (Palmisano \& Sullivan 1983, Grossi et al. 1984). The brine community appears to have many taxa in common with subsurface brine communities and internal ice assemblages reported from land-fast ice at other locations along the Antarctic coastline (McConville \& Wetherbee 1983, Takahashi et al. 1986) and with assemblages found in pack-ice (Garrison \& Buck 1989, 1991, Buck et al. 1992). In the Antarctic, pack ice is much more extensive than landfast ice, but most seasonal and experimental studies of sea ice biota have been conducted on bottom type microbial communities that are typical of land-fast ice (Garrison et al. 1986). There have been few time series or experimental studies of the surface-layer and interior microbial communities that are typical of pack ice because access to pack ice is difficult (Garrison 1991). The occurrence of an upper ice brine microbial community in McMurdo Sound allowed us to investigate seasonal changes in a land-fast ice community that had many environmental attributes (extremes of temperature and salinity, high irradiance during the austral spring and summer) and species in common with the pack ice microbial community.

In this study we report on the composition and successional changes in the upper ice brine community during the spring to summer transition in McMurdo Sound. It has been hypothesized that the extremes of temperature and salinity that occur in the upper ice at McMurdo limit microbial growth to the lower congelation ice (Kottmeier et al. 1985, Palmisano et al. 1987. Kottmeier \& Sullivan 1988). Temperatures of -24.0 to $0.0^{\circ} \mathrm{C}$ and brine salinities from 150 to $<20 \%$ have been reported in the upper layers of Antarctic sea-ice (Kottmeier et al. 1985, Kottmeier \& Sullivan 1988, Garrison \& Buck 1991). Our data indicate that a specialized set of photosynthetic protists actively grow in the brine and that some of them produce resting cysts (dinoflagellate hypnozygotes and chrysophyte statocysts) just prior to ice melt and break-out.

\section{METHODS}

This investigation was focused on changes in composition and abundance of the photosynthetic components of the microbial community found in the upper annual land-fast ice in McMurdo Sound during the spring to summer transition. To document seasonal patterns, the study was conducted during 2 field seasons. During the 1989-90 field season, samples were taken twice a week at the H89 site from 11 December to 1 January and at 14 locations in southeast McMurdo Sound between 12 December and 12 January (Fig. 1A; Stoecker et al. 1990). During the 1990-91 field season, samples (1 to 4 at each location) were taken at 12 locations on the eastern and 7 locations on the western side of McMurdo Sound between 30 November and 31 January (Fig. 1B; Stoecker et al. 1991). To better document successional changes, triplicate samples were taken at 1 location, H90, on 4 dates between 30 November 1990 and 5 January 1991 (Fig. 1B). Sampling after 5 January was not possible at $\mathrm{H} 90$ because of ice deterioration.

During the second field season, we took samples from sites on both the western side of the Sound and near the southern border of the annual sea ice as well as from the eastern side of the Sound in order to determine if the brine community was present in sea-ice throughout McMurdo Sound (Fig. 1B). To assess spatial variability on one date, samples were taken on 17 January 1991 at 4 widespread locations (Fig. 1B).

Samples were collected by drilling holes approximately $50 \mathrm{~cm}$ into the approximately $2 \mathrm{~m}$ thick annual ice with either a power drill or a Kovacs hand auger. Loose ice was removed and then the brine was allowed to accumulate in the hole until the brine level ceased to increase. The temperature of the brine was taken by immersing a thermometer in the brine in the hole (1990-91 season only). The accumulated brine was collected by gently pumping it with a hand vacuum pump into a bottle. The samples were then stored in a dark, insulated box until return within $3 \mathrm{~h}$ to the laboratory. During the 1990-91 season, a Sipre corer was used to collect a core from the upper $50 \mathrm{~cm}$ of ice at H90 on 30 November and 24 December. On 5 January the ice at H90 was too slushy to remove an intact core.

In the laboratory, the brine salinity and bulk salinity (from the melted Sipre cores) was determined with a refractometer. Brine volume was calculated from brine temperature and bulk salinity (Frankenstein \& Garner 1967). For chlorophyll determinations, triplicate $100 \mathrm{ml}$ samples were filtered onto GF/F glassfibre filters. The filters were extracted at $-20^{\circ} \mathrm{C}$ for $24 \mathrm{~h}$ in $90 \%$ acetone and the chlorophyll content determined by fluorometry (Parsons et al. 1984).

For enumeration of protists $<20 \mu \mathrm{m}$ in size, $50 \mathrm{ml}$ subsamples were preserved with glutaraldehyde (final conc. $0.3 \%$ ) and then 5 to $20 \mathrm{ml}$ volumes, as appropriate for the cell densities, were stained with proflavine (final conc. $0.5 \mu \mathrm{g} \mathrm{ml}^{-1}$ ) and collected onto $1.0 \mu \mathrm{m}$ pore size black-stained polycarbonate filters. Filters were mounted on slides and stored frozen until examination using epifluorescence microscopy (BP 450 to $490 \mathrm{~nm}$ excitation filter, FT $510 \mathrm{~nm}$ chromatic beam splitter, LP $520 \mathrm{~nm}$ barrier filter). Cells were classified as photosynthetic based on the presence of chlorophyll autofluorescence (modification of technique of Haas 1982). Cell sizes were measured with an ocular micrometer and converted to cell volumes using appropriate geometric formulae. 

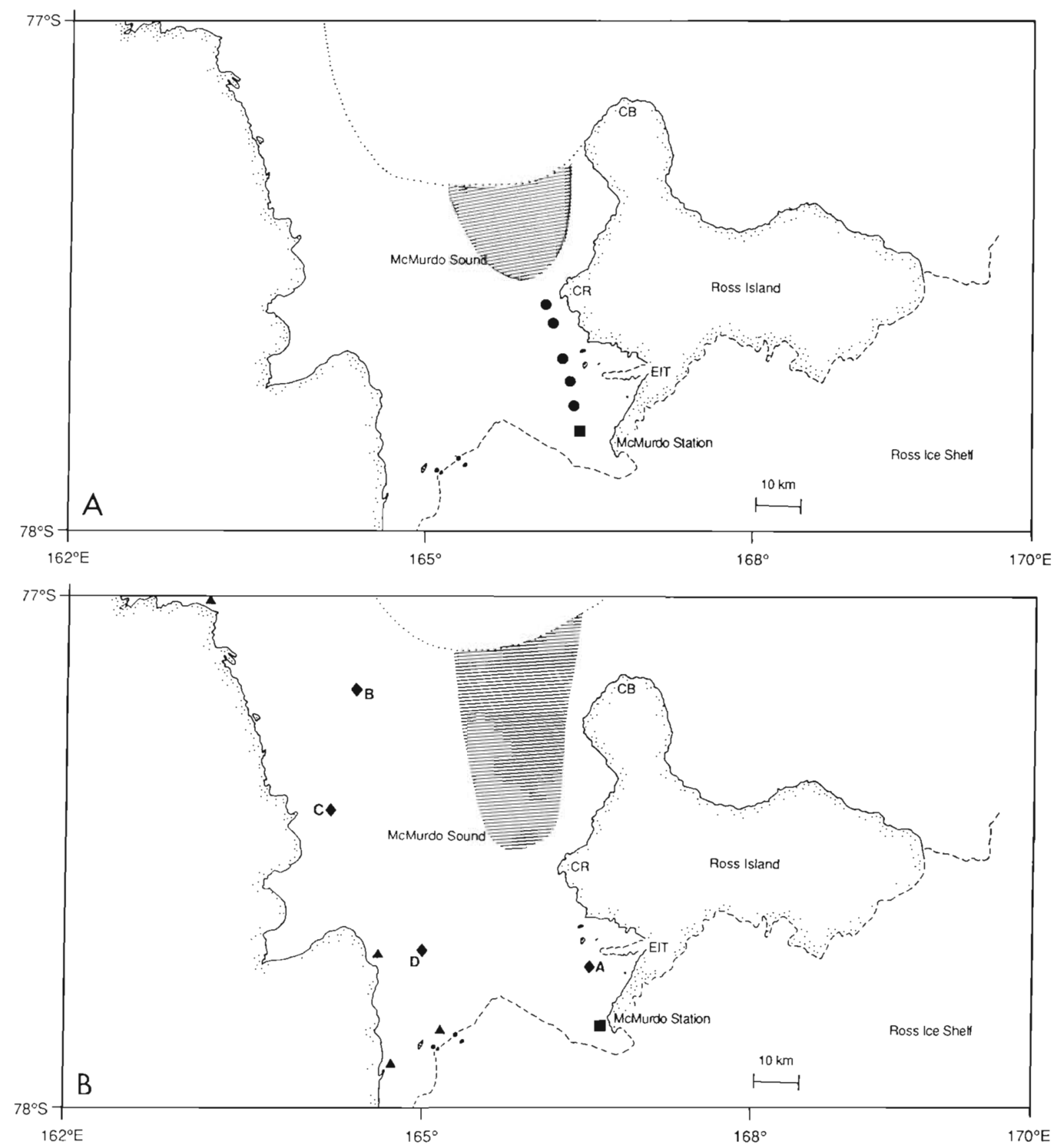

Fig. 1. Sampling locations during the (A) 1989-90 and (B) 1990-91 field seasons. (ש) Hut sites H89 (A) and H90 (B), where samples were taken several times during the season. Shading indicates areas on the SE side of McMurdo Sound within which during 1989-90 (A) 6 and during 1990-91 (B) 10 sites near the retreating ice edge were sampled. (-) Five sites along a transect on the SE side of McMurdo Sound sampled on 9 and $10 \mathrm{Jan} \mathrm{1990;} \mathrm{( \$ )} \mathrm{Stns} \mathrm{A,} \mathrm{B,} \mathrm{C} \mathrm{and} \mathrm{D} \mathrm{sampled} \mathrm{on} \mathrm{17} \mathrm{Jan} \mathrm{1991;} \mathrm{(4)} \mathrm{sites}$ where qualitative samples were taken to determine if the brine community occurred in the annual ice in all parts of the sound. (.....) Approximate location of ice edge at the beginning of our sampling season; (----) margin between the annual sea ice and the Ross Ice Shelf. $\mathrm{CB}=$ Cape Bryd, $\mathrm{CR}=$ Cape Royds, EIT = Erebus Ice Tongue

For enumeration of protists $\geq 20 \mu \mathrm{m}$ in size, $150 \mathrm{ml}$ samples were preserved with $10 \%$ acid Lugol's solution and $50 \mathrm{ml}$ settled samples were examined using an inverted microscope. To classify species as photosynthetic (plastidic) or not, representative samples were preserved in $2 \%$ (final conc.) buffered formaldehyde and examined using transmitted light and epifluorescence microscopy (Stoecker et al. 1989). 
Average cell volumes were determined based on formaldehyde-fixed specimens because shrinkage is less extreme than in Lugol's (Choi \& Stoecker 1989).

Various ratios have been used to convert biovolumes to biomass; the ratio appears to be influenced by taxon as well as fixation method. In the absence of empirically derived conversion factors for sea-ice protists, we decided to use the same conversion factor, $0.14 \mathrm{pgC}$ $\mu^{-3}$, for all taxa. This value has been suggested for dinoflagellates fixed with glutaraldehyde and for ciliates fixed with $2 \%$ formaldehyde (Putt \& Stoecker 1989, Lessard 1991).

For scanning electron microscopy (SEM), samples were preserved in $10 \%$ Bouin's solution and settled on polylysine coated coverslips. The samples were then post-fixed in osmium tetroxide, serially dehydrated in acetone in $10 \%$ steps and critically point dried (Thomsen et al. 1991).

\section{RESULTS}

\section{Physical-chemical parameters}

In late November, when our sampling program commenced, the land-fast sea ice was near its maximum extent in McMurdo Sound. Between December and January in both years, most of the annual land-fast ice in McMurdo Sound decayed and broke out (Fig. 1). By late January, frazil ice was beginning to form in the Sound. This seasonal cycle is reflected in the changes in brine temperature and brine salinity (Fig. 2). Between late November and the end of December, brine temperatures increased from about $-2.0^{\circ} \mathrm{C}$ to a high of $-0.2^{\circ} \mathrm{C}$; this corresponded to a decrease in brine salinity from 52 to about $15 \%$ (Fig. 2) and an increase in brine volume from a calculated $9.7 \%$ to $25 \%$ in the upper $50 \mathrm{~cm}$ of ice at the H90 location (data not shown). During January, temperatures in the brine declined and brine salinities were generally lower than that of seawater, salinities below $10 \%$ were occasionally observed (Fig. 2)

\section{Chlorophyll a}

Around 1 December, chlorophyll a values were about $0.75 \mu \mathrm{g} \mathrm{I}^{-1}$ in the brine (Fig. 3). With a brine volume of about $9.7 \%$, this would be a calculated chlorophyll content of $0.07 \mu \mathrm{g} \mathrm{I}^{-1}$ of ice volume. Chlorophyll $a$ (chl a) values in the brine peaked around the time of the austral summer solstice (Fig. 3) at about $3.5 \mu \mathrm{g} \mathrm{I}^{-1}$; with a brine volume of $25 \%$, this would result in a

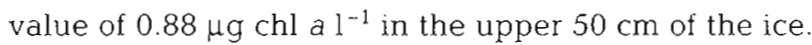
These rough calculations indicate that chlorophyll in
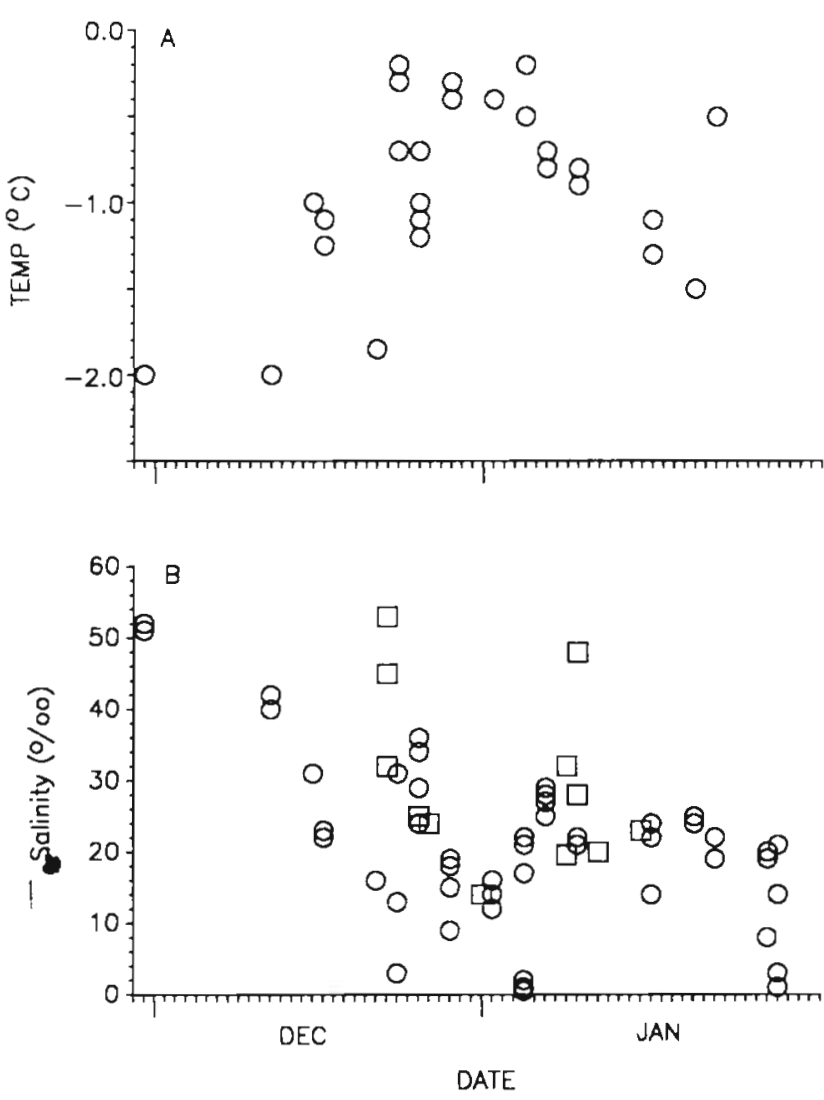

Fig. 2. Seasonal variation in (A) brine temperature (1990-91 data only) and (B) salinity. ( $\square$ ) 1989-90 data; (O) 1990-91 data

the upper $50 \mathrm{~cm}$ of ice increased by a factor of $12.5 \mathrm{dur}$ ing December 1990. Coincident with the increase in brine temperature and rapid decrease in brine salinity at the end of December (Fig 2), the chl a values in the brine dropped to $\leq 1.0 \mu \mathrm{g} \mathrm{l}^{-1}$ and stayed low throughout January.

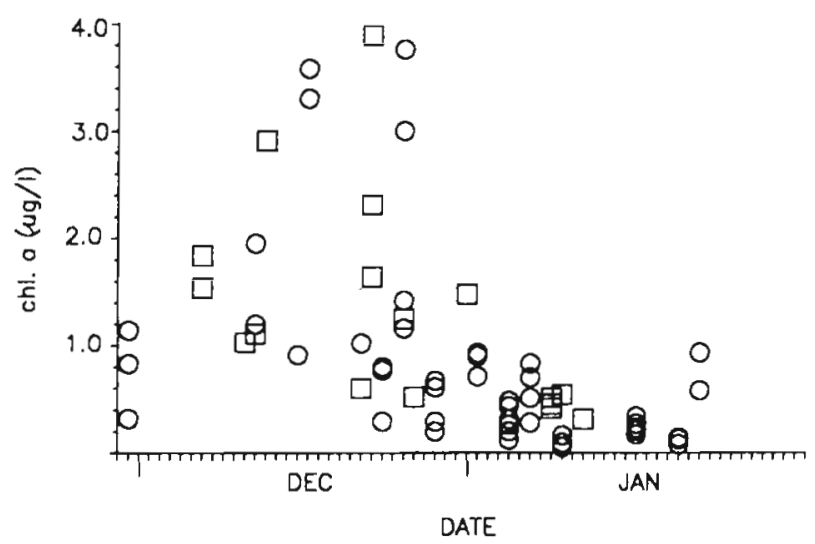

Fig. 3. Seasonal variation in chl a $\mathrm{ml}^{-1}$ brine. (口) 1989-90 data; (O) 1990-91 data 


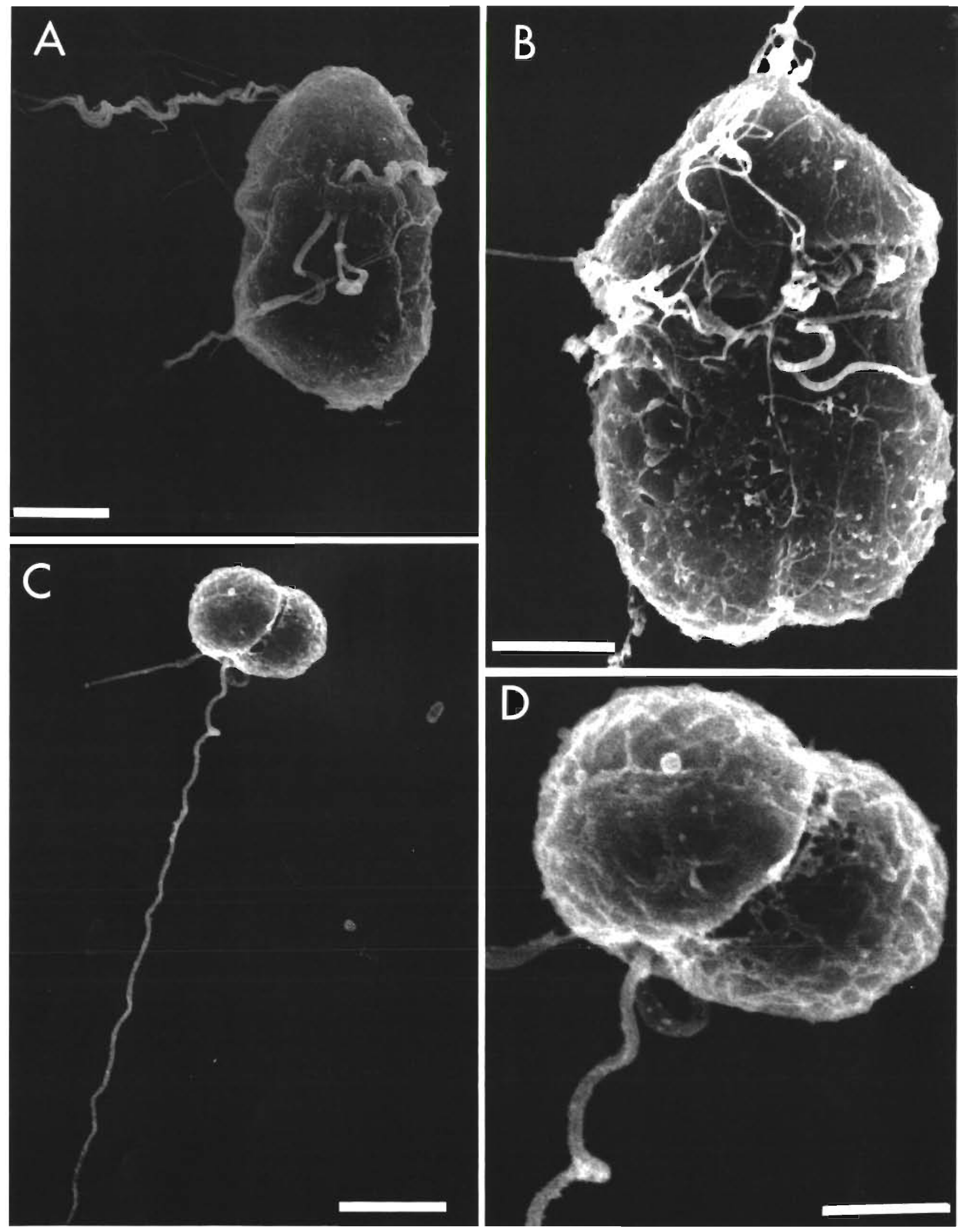

Fig. 4. Scanning electron micrographs of athecate, photosynthetic dinoflagellates from Antarctic sea ice; scale bar $=5 \mu \mathrm{m}$, except (D) where scale bar $=2 \mu \mathrm{m}$. (A) Small quadriflagellated planozygote. (B) Large quadriflagellated planozygote with trichocysts. Sulcal offset is ca $2 \mu \mathrm{m}$. (C) Vegetative cell of small dinoflagellate with long cingular (girdle) and short sulcal flagella. (D) Higher magnification showing the cingulum and the origin of the flagella in the small vegetative cell 

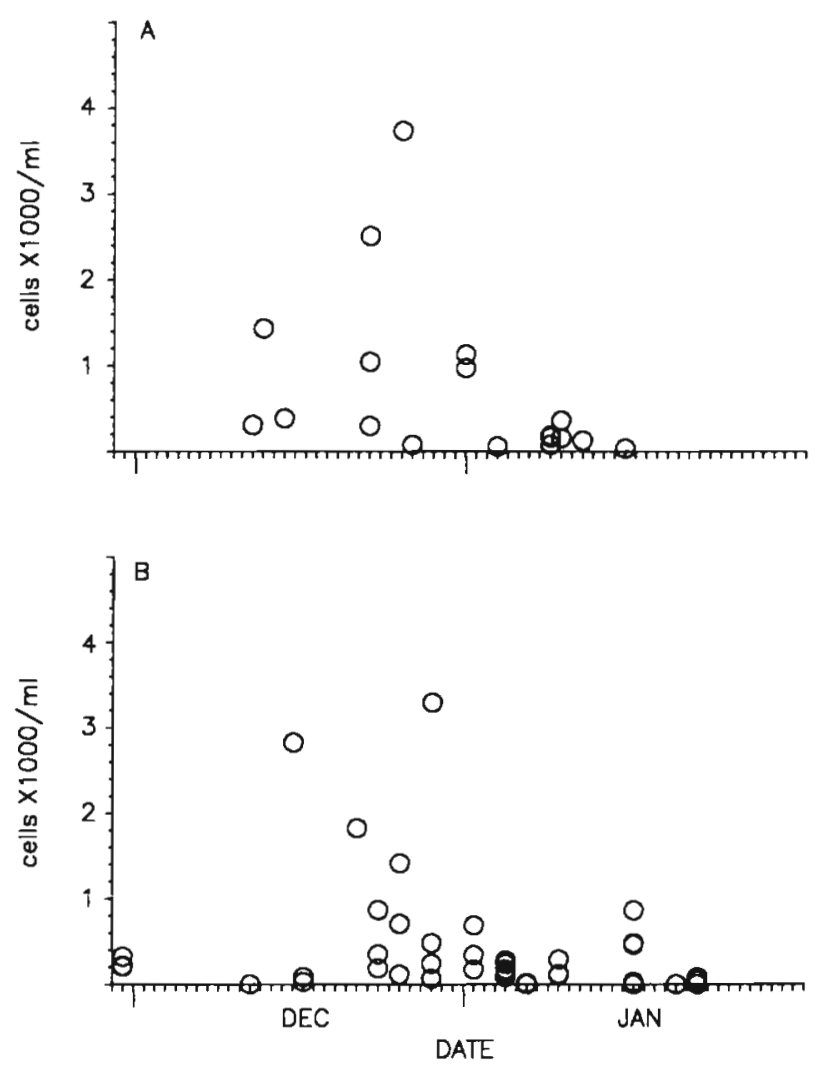

Fig. 5. Density $\left(\mathrm{ml}^{-1}\right.$ brine) of flagellated cells of the small photosynthetic gymnodinioid dinoflagellate (shown in Fig. 4C) during the (A) 1989-90 and (B) 1990-91 field seasons

\section{Photosynthetic protists}

At all locations and in all samples from the brine, we observed small photosynthetic dinoflagellates or their cysts (Fig. 4). The most common dinoflagellate was a small $(\sim 6 \times 10 \mu \mathrm{m})$ gymnodinioid species. Population densities were variable, but during December we observed cell densities of over $10^{3} \mathrm{ml}^{-1}$ of brine during both field seasons (Fig. 5).

At $\mathrm{H90}$ (Fig. 1), the density of the small dinoflagellate increased from 219 to 2796 cells $\mathrm{ml}^{-1}$ of brine between 30 November and 12 December 1990 (Table 1). Since brine volumes were increasing during this time, the dinoflagellate populations must have undergone a greater than 12.8-fold increase during this $12 \mathrm{~d}$ period.

In January, the cell density of the small dinoflagellate dropped to $<10^{3}$ cells $\mathrm{mi}^{-1}$ of brine throughout McMurdo Sound (Fig. 5). At H90, the small dinoflagellate had a density of 230 cells $\mathrm{ml}^{-1}$ of brine on 5 January 1991 (Table 1). During mid to late December, hypnozygotes of this dinoflagellate (Fig. 4) first appear in the brine (Fig. 6, Table 1). The hypnozygotes were $12 \mu \mathrm{m}$ cysts with recurved spines (Fig. 4). These cysts
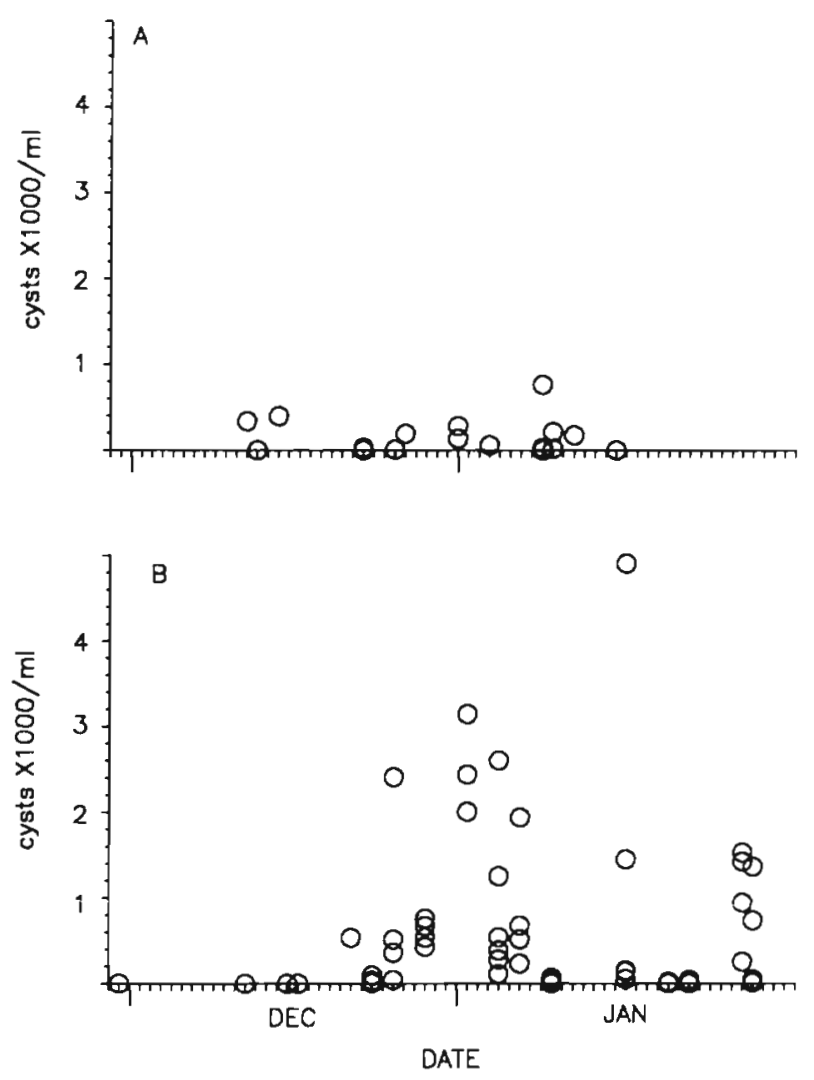

Fig. 6. Density ( $\mathrm{ml}^{-1}$ brine) of cysts (hypnozygotes) of the small photosynthetic gymnodinioid dinoflagellate during the (A) 1989-90 and (B) 1990-91 field seasons

are morphologically indistinguishable from ones observed in pack ice by Buck et al. (1992). During early January 1991, we observed cyst densities of over $10^{3}$ $\mathrm{ml}^{-1}$ of brine in several samples. At H90, we observed an average of 259 dinoflagellate cysts $\mathrm{ml}^{-1}$ of brine on 5 January 1991 (Table 1).

At some locations, we also observed larger photosynthetic dinoflagellates (Fig. 4). These cells varied from 17 to $40 \mu \mathrm{m}$ in size. Examination by SEM indicates that this size class included planozygotes of the small gymnodinioid dinoflagellate (Fig. 4A) as well as a larger athecate dinoflagellate species (Fig. 4B). All of the large dinoflagellate cells we examined with SEM were planozygotes, but vegetative cells of this species may also have been present in our samples. Photosynthetic dinoflagellates in the $\geq 17 \mu \mathrm{m}$ size class were not found in all samples and seemed to be extremely variable in occurrence (Fig. 7). The dinoflagellates in this size class occurred at lower densities than the small vegetative gymnodinioid cells except in the 30 November samples from H90 (Table 1). By the end of December, the larger photosynthetic dinoflagellates were rare in all samples (Fig. 7. Table 1). 
Table 1. Changes in physical and chemical properties of brine at H90 during late austral spring and early summer, $1990-1991$

\begin{tabular}{|c|c|c|c|c|}
\hline & $30 \mathrm{Nov}$ & $12 \mathrm{Dec}$ & $24 \mathrm{DeC}$ & $5 \mathrm{Jan}$ \\
\hline Brine temperature $\left({ }^{\circ} \mathrm{C}\right)^{a}$ & -2.0 & -2.0 to -1.3 & -0.7 to -0.2 & -0.2 to 0.0 \\
\hline Salinity $(\%)$ & 51 to 52 & 31 to 42 & 3 to 31 & $<1$ to 2 \\
\hline Autotrophs (cells $\left.\mathrm{ml}^{-5}\right)^{b}$ & & & & \\
\hline $\begin{array}{l}\text { Dinoflagellates } \\
\quad \text { Flagellated cells } \leq 10 \mu \mathrm{m} \\
\text { Flagellated cells }>10 \mu \mathrm{m} \\
\text { Cysts }(12 \mu \mathrm{m})\end{array}$ & $\begin{array}{c}219(37) \\
404(76) \\
0\end{array}$ & $\begin{array}{c}2796(226) \\
102(37) \\
0\end{array}$ & $\begin{array}{c}467(203) \\
9(9) \\
43(28)\end{array}$ & $\begin{array}{c}230(32) \\
0 \\
259(81)\end{array}$ \\
\hline $\begin{array}{l}\text { Non-flagellates } \\
\quad 2-4 \mu \mathrm{m} \\
\quad 26 \mu \mathrm{m} \text { chrysophyte cysts }\end{array}$ & $\begin{array}{c}1421(225) \\
0\end{array}$ & $\begin{array}{c}1679(579) \\
135(116)\end{array}$ & $\begin{array}{c}807(294) \\
65(50)\end{array}$ & $\begin{array}{l}517(168) \\
653(283)\end{array}$ \\
\hline $\begin{array}{l}\text { Plastidic ciliates } \\
\text { Strombidium spp. } \\
\text { Mesodinium rubrum }\end{array}$ & $\begin{array}{c}0.12(0.03) \\
0\end{array}$ & $\begin{array}{l}\text { ND } \\
\text { ND }\end{array}$ & $\begin{array}{l}0.11(0.11) \\
0.10(0.05)\end{array}$ & $\begin{array}{l}0 \\
0\end{array}$ \\
\hline
\end{tabular}

Small $(\leq 5 \mu \mathrm{m})$ photosynthetic cells and cysts occurred in most samples (Fig. 8, Table 1). This category included Mantoniella sp. (Fig. 9D) and small siliceous cyst-like forms (Fig. 9B) that were reminiscent of cyst
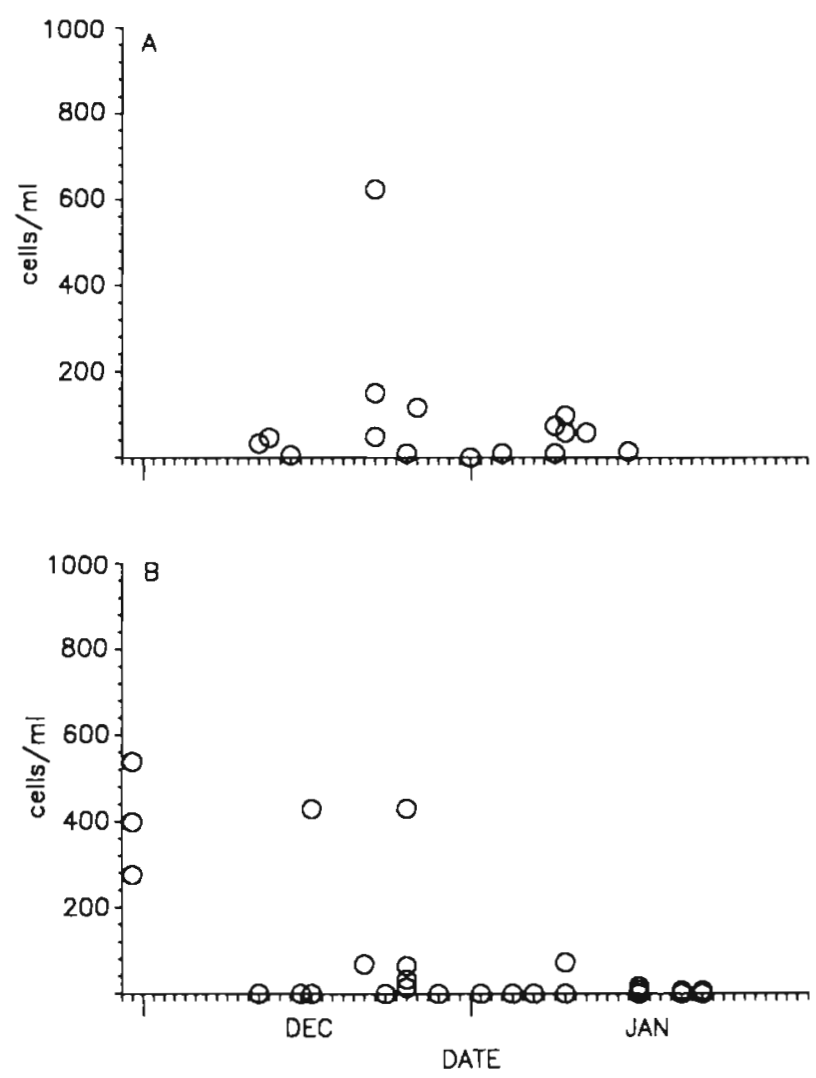

Fig. 7. Density ( $\mathrm{ml}^{-1}$ brine) of $\geq 12 \mu \mathrm{m}$ photosynthetic dinoflagellates during the (A) 1989-90 and (B) 1990-91 field seasons. This size class included planozygotes of the small gymnodinioid species and cells of a larger species type '1B' observed by Takahashi et al. (1986) in the land-fast ice near Syowa Station. Phaeocystis sp. was present in about one-third of the samples; the average density of this species was about $100 \mathrm{ml}^{-1}$ (data not
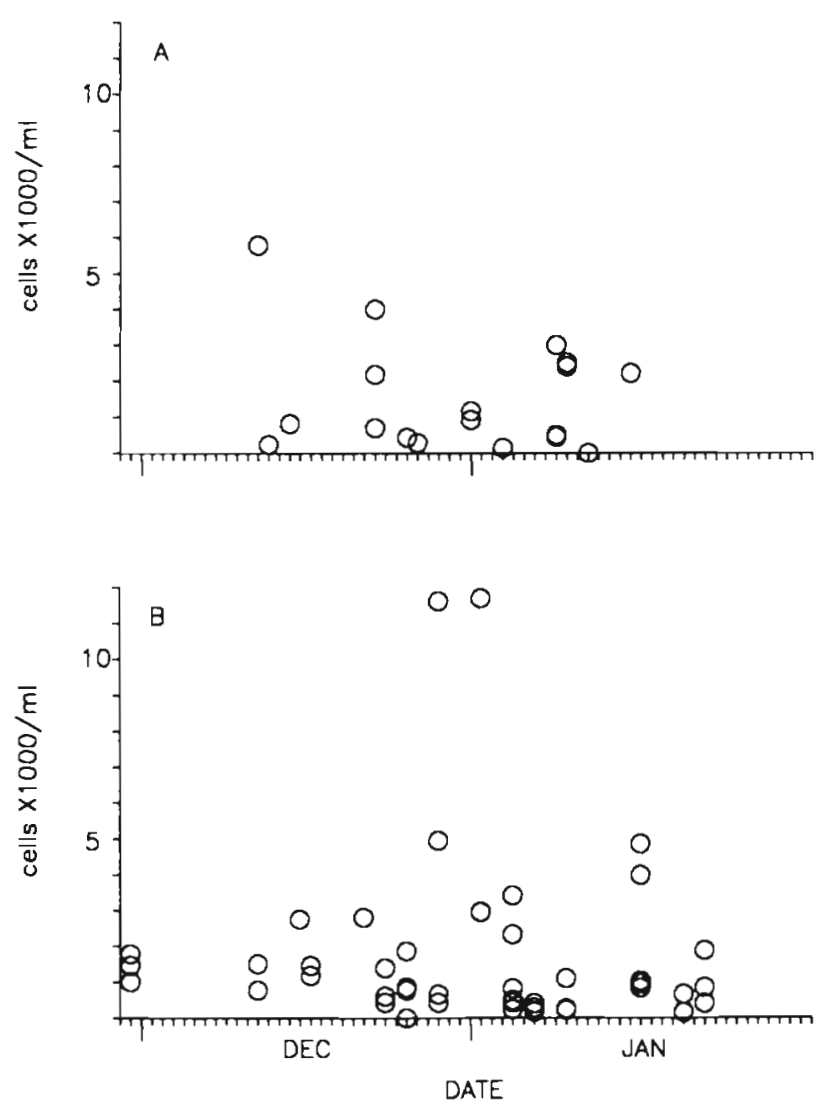

Fig. 8. Density ( $\mathrm{ml}^{-1}$ brine) of $\leq 5 \mu \mathrm{m}$ photosynthetic protists during the (A) 1989-90 and (B) 1990-91 field seasons 

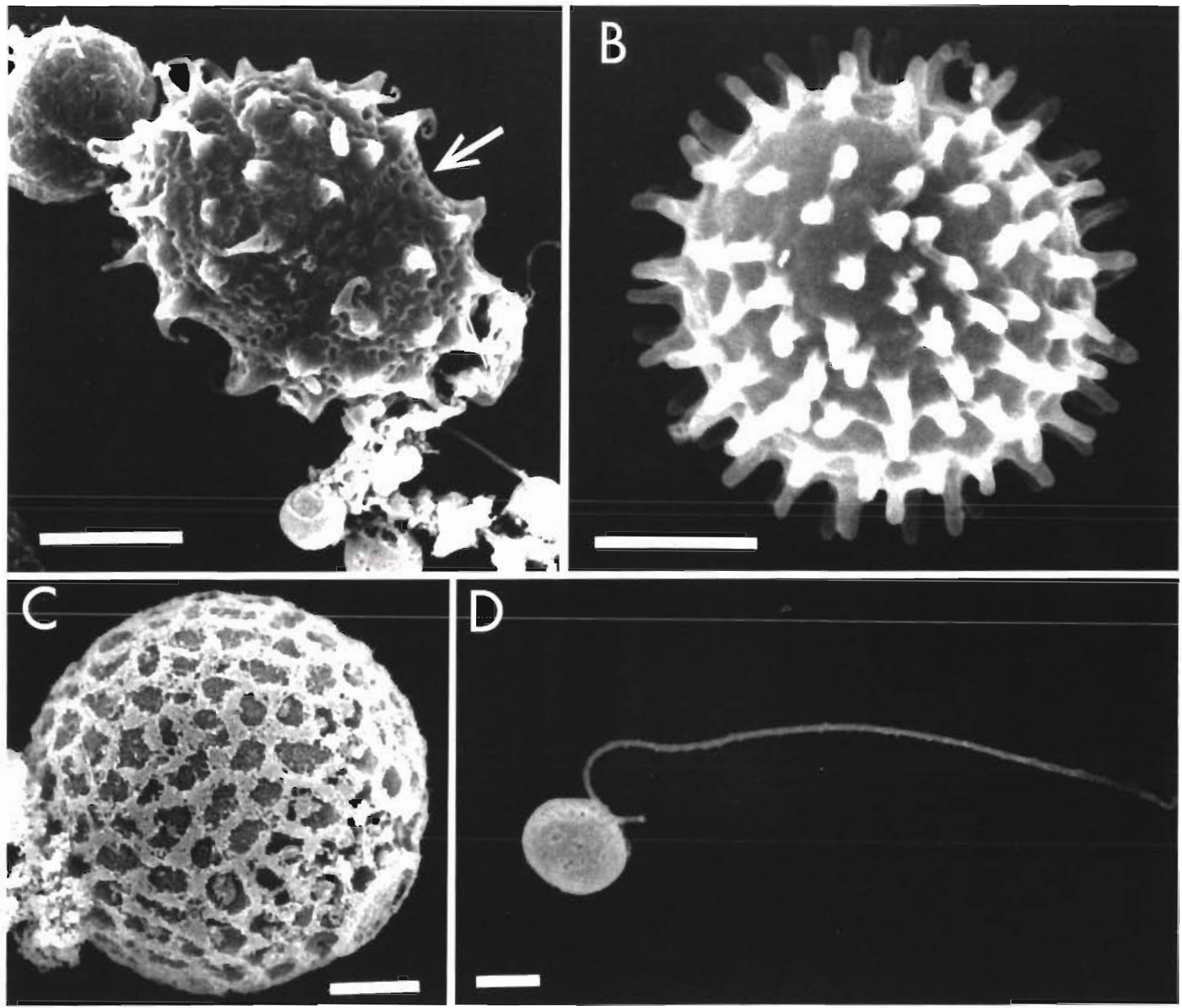

Fig. 9 Scanning electron micrographs of cysts and small photosynthetic protists from Antarctic sea ice. Scale bar $=2 \mu \mathrm{m}$ except (A) where scale bar $=5 \mu \mathrm{m}$. (A) Hypnozygote (cyst) of the small photosynthetic gymnodinioid dinoflagellate with cingulum (girdle) indicated by an arrow and intratabular processes (spines). Also present are a gymnodinioid vegetative cell (upper lefthand corner) and several Mantoniella sp. cells (lower right-hand corner). (B) Small siliceous cyst-like organism of unknown affinity. No opercula or plugs were observed in conjunction with these organisms. (C) Chrysophyte statocysts with characteristic reticulation and collar encircling the plug. (D) Mantoniella sp. with one long and one short flagellum

shown). The $<5 \mu \mathrm{m}$ photosynthetic cells (all types combined, except for diatoms) varied in abundance from about $10^{3}$ to $10^{4}$ cells $\mathrm{ml}^{-1}$ of brine (Fig. 8)

We observed thick-walled chrysophyte statocysts 6 to $10 \mu \mathrm{m}$ in diameter (Fig. 9). The statocysts had a bright red (and sometimes also yellow) autofluorescence. They were similar in morphology to silicious cysts which have been described from pack ice in the Weddell Sea by Silver et al. (1980) and from land-fast ice in east Antarctica by Takahashi et al. (1986). We found chrysophyte statocysts from mid-December through January in the brine, but they were not found in all samples (Fig. 10). At H90, they were not observed in the triplicate samples from 30 November, but were observed in samples from later dates (Table 1). Statocysts were not observed or were rare in the brine in the early austral spring, but densities of over $500 \mathrm{ml}^{-1}$ of brine were common in late December and January (Fig. 10). These data suggest that the statocysts were produced in situ.

Diatoms occurred in about one-third of the samples, the most common species was a $2 \times 8-10 \mu \mathrm{m}$ pennate Average diatom densities were $<10 \mathrm{ml}^{-1}$ (data not shown) 

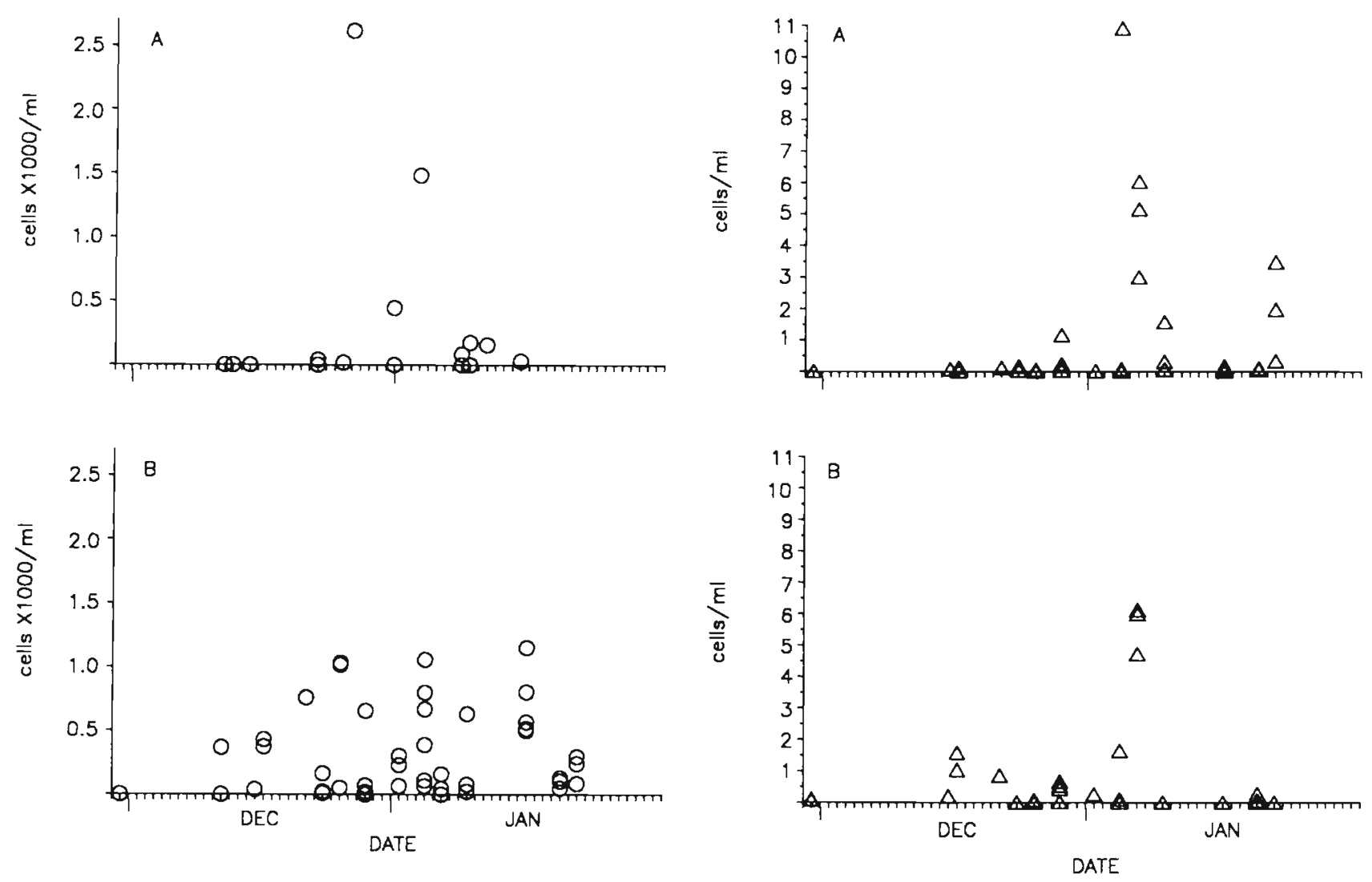

Fig. 10. Density (m- ${ }^{-1}$ brine) of 6 to $10 \mu \mathrm{m}$ chrysophyte statocysts (archaeomonads) during the (A) 1989-90 and (B) 1990-91. field seasons

Fig. 11 Density ( $\mathrm{m}^{-1}$ brine) of (A) Mesodinium rubrum and (B) plastidic Strombidium spp. 1990-91 data only

In some brine samples we observed photosynthetic ciliates, inclucing small (15 to $20 \mu \mathrm{m})$ and mediumsized (20 to $40 \mu \mathrm{m}$ ) Mesodinium rubrum and plastidic oligotrichs (Strombidium spp.) (Fig. 11). During January, Mesodinium reached densities of over $5 \mathrm{ml}^{-1}$ in some samples. The most common photosynthetic oligotrich was a $25-30 \mu \mathrm{m} \times 50-60 \mu \mathrm{m}$ conical Strombidium sp. which appeared to contain isolated plastids (Stoecker, 1991); this species occurred in some samples at densities of over $5 \mathrm{ml}^{-1}$. The occurrence of photosynthetic ciliates in the brine was extremely variable (Fig. 11), with many samples not containing them.

\section{Biomass}

Seasonal trends in the biomass of photosynthetic protists were evident at both $\mathrm{H} 90$ (Fig. 12) and in samples from various locations on the ice (Fig. 13). At H90, total biomass of autotrophs decreased from $>200 \mathrm{ng} \mathrm{C}$ $\mathrm{ml}^{-1}$ to $<50 \mathrm{ng} \mathrm{ml}^{-1}$ of brine between the end of November and the beginning of January (Fig. 12). During December 1990, the average biomass of photosynthetic protists was about $125 \mathrm{ng} \mathrm{C} \mathrm{ml}{ }^{-1}$, while it

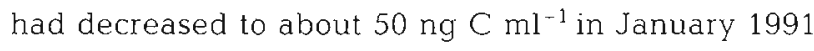
(Fig. 13).

Photosynthetic dinoflagellates and their cysts dominated the biomass (Figs. 12 \& 13), comprising over $80 \%$ of the autotrophic biomass in December and over $50 \%$ in January. During December, motile dinoflagellates made up most of the autotrophic biomass, in January dinoflagellate cysts dominated the biomass. At $\mathrm{H} 90,6$ to $10 \mu \mathrm{m}$ chrysophyte statocysts were a dominant component of the autotrophic biomass in early January, but overall the $<5 \mu \mathrm{m}$ category contributed more to biomass than the larger chyrsophyte statocysts (Fig. 12). Diatoms and plotosynthetic ciliates each contributed, on average, $<5 \%$ of the autotrophic biomass (data not shown).

Although seasonal trends in biomass were evident both at $\mathrm{H} 90$, which was sampled on 4 dates, and at samples taken from various locations on the ice, there was also considerable spatial variability in biomass (Fig. 14). On 17 January 1991, total autotrophic biomass per unit brine ranged from a low of $22 \mathrm{ng} \mathrm{C} \mathrm{ml}^{-1}$ at $\operatorname{Stn} A$ near the ice edge, to a high of $188 \mathrm{ng} \mathrm{C} \mathrm{ml}^{-1}$ at Stn $C$ on the west side of the sound (Figs. $14 \& 1 B$ ). 


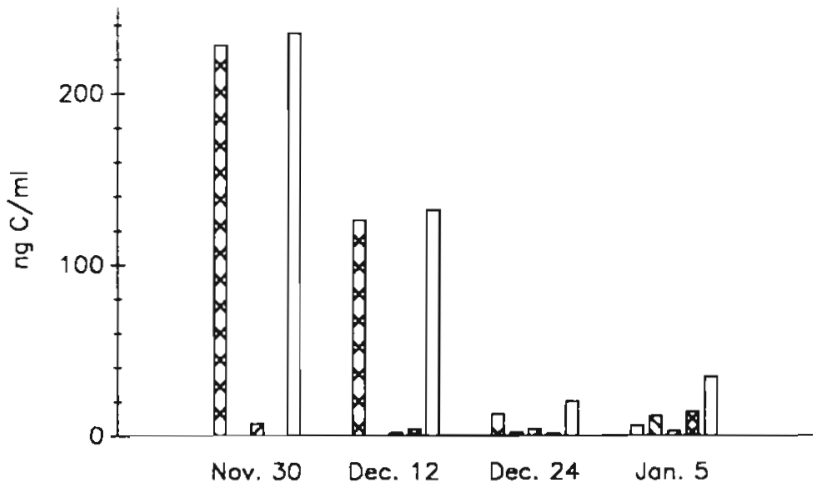

Fig. 12. Changes in the biomass at H90 during the 1990-91 field season of $(\bigotimes)$ photosynthetic dinoflagellates; ( dinoflagellate hypnozygotes (cysts); $(\mathbb{Z}) \leq 5 \mu \mathrm{m}$ photosynthetic protists: chrysophyte statocysts; and (口) total photosynthetic biomass

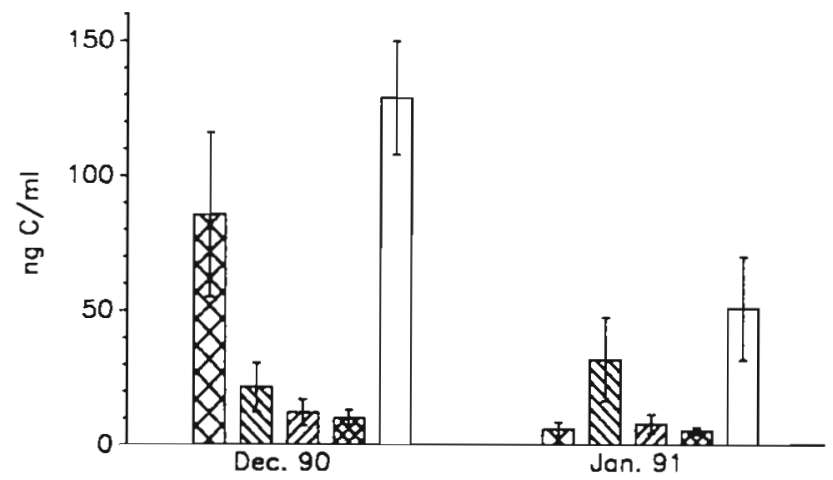

Fig. 13. Average biomass during December 1990 and January 1991 Data from all. locations were averaged for each month. See Fig. 12 for explanation of bars

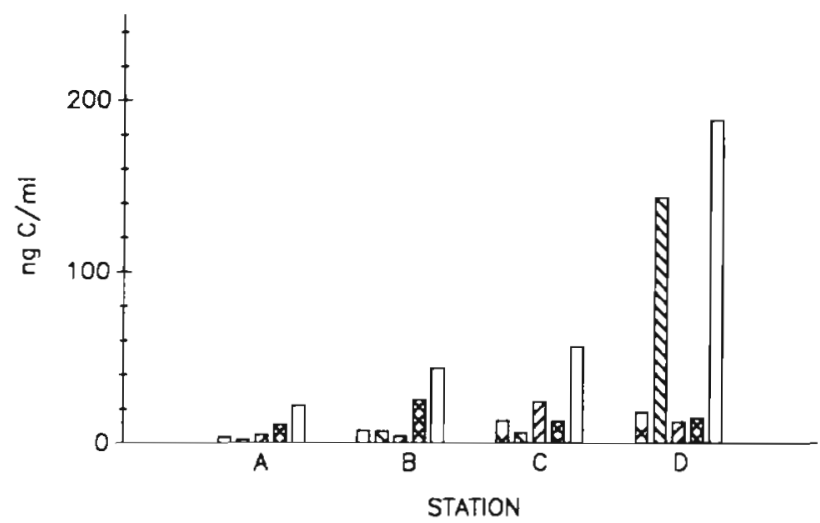

Fig. 14. Spatial variability $m$ biomass at Stns $A, B, C$ and $D$ (see Fig. 1B) on 17 January 1991. See Fig. 12 for explanation of bars

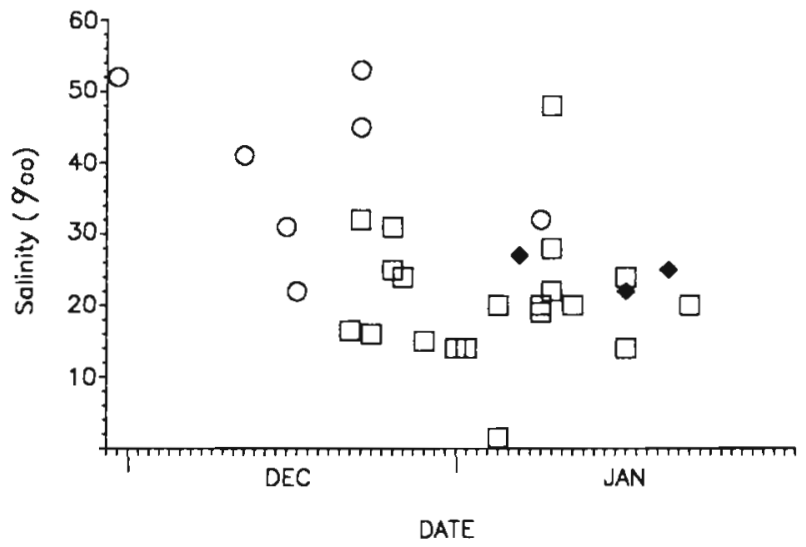

Fig. 15. Occurrence of flagellated life history stages of $(0)$ photosynthetic dinoflagellates; $(\square)$ flagellated cells and their cysts; or ( their cysts in McMurdo Sound upper ice brine during both field seasons. Each symbol represents one sample location/date. After mid-December, dinoflagellate cysts were found in most samples and brine salinities were usually $<32 \%$. At all sample locations/dates, photosynthetic dinoflagellates and/or their cysts were found in the brine

\section{DISCUSSION}

The dinoflagellate-dominated brine community appears to be a re-occurring feature of the upper landfast sea-ice in McMurdo Sound. During both years of our study, this assemblage was present during the spring-summer transition and underwent similar successional changes although the exact timing and magnitude of the changes differed slightly between the 2 years. We found this community at every location we sampled on the land-fast ice in McMurdo Sound. However, we do not know if this community occurs in land-fast ice at other locations along the Antarctic coastline

Compared to the diatom-dominated bottom type ice communities at McMurdo, the chl a concentration in the upper ice brine is low; the highest chlorophyll concentrations we observed were ca $4 \mu \mathrm{gl}^{-1}$ in the upper ice brine. At times the chlorophyll concentration in the bottom $20 \mathrm{~cm}$ of ice can reach $656 \mu \mathrm{g} \mathrm{l}^{-1}$ (Palmisano \& Sullivan 1983), but it is important to remember that the bottom type community is very patchy in distribution (McConville \& Wetherbee 1983, Palmisano \& Sullivan 1983)

The upper ice brine community in the fast ice at McMurdo is more similar to the surface-layer and internal ice communities reported from pack ice (Garrison \& Buck 1989, 1991) than to bottom type landfast ice microbial communities. Chl a levels in our brine samples were comparable to chlorophyll levels in first year pack ice but about an order of magnitude lower than levels reported in cores from multi-year 
pack ice (Garrison \& Buck 1989, 1991). Surface-layer assemblages from the Weddell Sea pack ice are very variable in chlorophyll concentration, ranging from 0.1 to $54.0 \mu \mathrm{g} \mathrm{chl} \mathrm{a}^{-1}$ of brine or slush, but with more than half the samples containing $<5 \mu \mathrm{g}$ chl a $\mathrm{l}^{-1}$ (Garrison \& Buck 1989, 1991). Thus, the chlorophyll values we observed in upper layer land-fast ice brine are within the lower range of those reported from pack ice surface brine. Likewise, photosynthetic biomass in the upper land-fast ice brine (range ca 20 to $220 \mathrm{ng} \mathrm{C} \mathrm{ml}^{-1}$ ) is similar to values reported from about $70 \%$ of the brine samples from surface pack ice. In samples from the pack ice brine pockets, a few extremely high chl $a$ and biomass levels are reported (Garrison \& Buck 1991). thus development of the brine community in pack ice seems to be much more variable than in land-fast ice.

Although pack ice (Garrison \& Buck 1989) and landfast ice brine appear to have many dominant taxa in common, the composition of the pack ice is more diverse and variable. The greatest difference in community composition appears to be the dominance of diatoms in many brine samples from pack ice (Garrison \& Buck 1989, 1991) and their comparative scarcity in brine samples from the upper land-fast ice.

Pack ice usually contains a larger frazil ice component and is usually more heterogenous than annual land-fast ice (reviewed in Garrison 1991). In the Weddell Sea, pack ice is composed of both first year and multiyear sea ice and thus floes or parts of floes may have radically different histories. Formation of infiltration ice at the snow-water interface appears to be more common in pack ice than in land-fast ice, which should increase biological variability (reviewed in Garrison 1991). We hypothesize that the more complex physical structure and history of pack ice is responsible for the greater variability observed in the composition and abundance of photosynthetic protists in pack-ice brine communities than in land-fast sea-ice brine communities. Consequently, land-fast sea-ice brine communities may be excellent experimental systems in which to investigate the life histories and the physiological ecology of sea-ice biota which occur in both types of environments.

During austral spring, dinoflagellate populations reach densities of over $10^{3} \mathrm{ml}^{-1}$ and dominate the autotrophic biomass in the upper ice brine. Although dinoflagellates have been reported previously from pack ice (Garrison \& Buck 1991), the observation of 'bloom' densities in the upper ice brine was surprising. Dinoflagellates are rare or absent from most hypersaline habitats (Wright \& Burton 1981, Javor 1989). Data from H90 suggest that the dinoflagellates started to grow in the brine prior to our first sample 130 November) when salinities must have been $>50 \%$ and temperatures $<-2.0^{\circ} \mathrm{C}$.
The growth of Chlorophyta and Chrysophyta is perhaps less surprising, these taxa have been previously reported from sea-ice (reviewed in Garrison 1991) and are often dominant inhabitants of extreme environments such as hypersaline lagoons (Javor 1989) and snow algal assemblages (Vincent 1988).

During winter and early spring, the temperature and salinity regime in the upper ice brine pockets is extreme compared with the lower congelation ice, platelet ice or underlying water column, but in some respects the brine pockets may be a more favorable habitat for algal growth than these other habitats. When sea-ice is initially formed, salts, including nutrients for algal growth, are excluded forming the hypersaline brine (Lake \& Lewis 1970); thus, initial nutrient concentrations in brine are predicted to be high compared to seawater (Garrison et al. 1990). However, nutrient depletion may occur in the brine pockets and channels as the growing season progresses (Dieckmann et al. 1991). The high algal biomass at the base of the sea-ice in McMurdo Sound is thought to be supported by substantial nutrient fluxes from the water column (Cota \& Sullivan 1990).

The upper sea-ice is a high light environment compared to the base of the sea-ice or the underlying water column. In early spring, when light is limiting to plant growth, the ice is particularly transparent (Buckley \& Trodahl 1990). In late November in McMurdo Sound, Arrigo et al. (1991) measured photosynthetically availble radiation (PAR) of approximately $425 \mu \mathrm{E} \mathrm{m}^{-2} \mathrm{~s}^{-1}$ at a depth of about $10 \mathrm{~cm}$ into the congelation ice, the position where the brine pockets are concentrated (Buckley \& Trodahl 1990), but an under-ice PAR ranging from only about 25 in late September to $2 \mu \mathrm{E} \mathrm{m} \mathrm{m}^{-2}$ $\mathrm{s}^{-1}$ in early December. Assuming miminal snow cover with an albedo of about 0.75 and a $K_{\mathrm{D}}$ of $1.5 \mathrm{~m}^{-1}$ (Arrigo et al. 1991), about $18 \%$ of the incident irradiation should penetrate to about $10 \mathrm{~cm}$ into the congelation ice. In contrast, under-ice irradiance is generally $<1 \%$, and sometimes $<0.1 \%$ of incident surface irradiance during the austral spring in McMurdo Sound (SooHoo et al. 1987). Algal growth at the base of the sea-ice and in the underlying water column is further limited by spectral quality, most of the light which penetrates to the base of the sea-ice is concentrated in the green region of the spectrum where microalgae do not absorb light effectively (SooHoo et al. 1987).

During austral spring, the presence of brine pockets and of photosynthetic protists in these pockets probably accelerates melting, thus increasing brine volume (ice porosity) and weakening ice structure (Meguro 1962, Buynitskiy 1968, McConville \& Wetherbee 1983, Maykut 1985, Eicken et al. 1991). Water has a lower albedo and a higher heat capacity than ice, therefore the presence of brine pockets themselves would tend 
to increase local absorbance of light, resulting in localized heating and expansion of the brine pockets (Vincent 1988). The absorbance of light and localized heating should be enhanced by the presence of photosynthetic organisms and other particulates in the brine. The efficiency of photosynthesis, in terms of absorbed light energy, is usually $\leq 25 \%$ (Platt \& Jassby 1976 , Platt et al. 1984); $\geq 75 \%$ of the absorbed light energy is directly converted into heat (Lewis et al. 1983). The affects of chlorophyll concentration on thermal structure and localized melting of sea ice should be quite significant because of relatively low rates of convectional heat transfer (mixing) in sea-ice systems. Therefore, during early austral spring, a positive feedback is hypothesized to exist between expansion of brine pockets and growth of photosynthetic microorganisms. In McMurdo Sound, the brine volume of the surface ice layer increases dramatically in early November, resulting in reduced percent transmittance of light to the lower ice and water column until the ice breaks out (Buckley \& Trodahl 1990).

During spring, another advantage to living in the brine may be relative freedom from predation. Although microbial predators, such as Cryothecomonas spp. (Garrison \& Buck 1991, Thomsen et al. 1991) occur in the brine, larger microbial and metazoan grazers are rare in annual land-fast ice brine pockets during early spring (Stoecker unpubl.). However, in late December and January, microbial grazers from the water column invade the upper ice brine (Stoecker unpubl.)

The most dramatic change in the upper ice brine community during late austral spring and early summer is the formation of cysts. The small cyst-forming gymnodinioid dinoflagellate was found at all sites sampled. This cyst is quite unusual and distinctive (Buck et al. 1992); most gymnodinioids are thought to produce mucoid cysts rather than thick-walled cysts such as we and Buck et al. (1992) observed. During late November and early December, only swimming cells of the dinoflagellate were observed, but by mid-December dinoflagellate cysts were observed at most sites and in January dinoflagellate cysts predominated (Fig. 15).

Although chrysophyte statocysts were not as ubiquitous as the dinoflagellate cysts, they were observed in most brine samples taken from mid-December through January. Dinoflagellate cyst formation and perhaps also formation of chrysophyte statocysts coincides with a drop in brine salinity to $\leq 30 \%$, although changes in salinity probably do not trigger cyst-formation (Stoecker unpubl.). Surface melt and major changes in ice salinity generally coincide with flushing of the ice (Weeks \& Ackley 1982). From early January onward, dinoflagellate cysts and chrysophyte statocysts were observed free in the water column or in fecal pellets in the water column (Stoecker \& Putt unpubl.). The same or very similar dinoflagellate cysts and chrysophyte statocysts have been observed in association with seaice from other Antarctic locations (Silver et al. 1980, Takahashi et al. 1986, Buck et al. 1992).

During late December and January, photosynthetic biomass $\mathrm{ml}^{-1}$ of brine decreases drastically. This is probably because of a combination of physical and biological factors. Due to surface melt, brine volume increases rapidly during late spring and summer; this must dilute populations within the brine. At the same time, brine is flushed into the water column (Weeks \& Ackley 1982), thus removing some of the biomass. Biological factors, including cyst formation $(2$ vegetative cells produce 1 hypnozygote) and grazing, may also contribute to the observed decreases in population density $\mathrm{ml}^{-1}$ of brine.

Our data suggest that a specific set of photosynthetic protists are adapted to life in sea-ice brine and are characteristically associated with it. The small gymnodinioid dinoflagellate produces cysts after a period of vegetative growth in the brine. Our observation that abundance in the brine of chrysophyte statocysts increases during late austral spring is in accord with the conclusion of Takahashi et al. (1986) that the statocysts are produced from mother cells that grow in the seaice. Resting stages are formed prior to or during ice melt and break-up and thus may be an adaptation for survival in the water column. Chrysophyte statocysts (archaeomonads) have been suggested as indicators of sea-ice conditions in the fossil record (Mitchell \& Silver 1982). Use of dinoflagellate cysts as palaeoenvironmental indicators is also developing (reviewed in Goodman 1987). The cysts of brine organisms may be excellent markers in the sedimentary record for annual sed ice.

Acknowledgements. The authors thank Ms Jessie Alstatt, Ms Gerri Miceli, Ms Tiffany Moisan and Mr Erik Zettler for field assistance, sample analysis and good comradery, Ms L. H. Davis for laboratory assistance, U.S. Navy Antarctic Development Squadron Six (VXE-6), the staff of the Berg Field Center and the Eklund Biological Laboratory for excellent support. We thank Dr G. Dieckmann for suggesting that we sample the upper ice brine and Drs T Hoshiai, S Kottmeier, H. Meguro, S. W. Sullivan, A. Taniguchi, E Takahashi, and $\mathrm{K}$. Watanabe for sharing their knowledge of sea-ice microbial communities with us. This work was supported by NSF grant DPPO-8816668 to M.P. and D.K.S. The Japanese Society for the Promotion of Science made possible the visit of D.K.S. to the National Institute for Polar Research in Tokyo.

\section{LITERATURE CITED}

Arrigo, K. R., Sullivan, C. W., Kremer, J. N. (1991). A biooptical model of Antarctic sea ice. J geophys. Res. 96: 10581-10592 
Buck, K. R., Bolt, P., Benthan, W. N., Garrison, D. L. (1992). A. dinoflagellate cyst from Antarctic sea ice. J. Phycol. 28: $15-18$

Buckley, R. G., Trodahl, H. J. (1990). Scattering and absorption of light by sea ice. In: Ackley, S. F., Weeks, W. F. (eds.) Sea ice properties and processes. CRREL Monograph 901. U.S. Army Corps of Engineers Cold Regions Research \& Engineering Laboratory, Hanover, p. 49-52

Buynitskiy, V.K. (1968). The influence of microalgae on the structure and strength of Antarctic sea ice. Oceanology 8 : $771-776$

Choi, J. W., Stoecker, D. K. (1989). Effects of fixation on cell volume of marine planktonic Protozoa. Appl. environ. Microbiol. 55: 1761-1765

Cota, G. F., Sullivan, C. W. (1990). Photoadaptation, growth and production of bottom ice algae in the Antarctic. J. Phycol. 26: 399-411

Dieckman, G. S., Lange M. A., Ackley, S. F., Jennings, J. C. Jr (1991). The nutrient status in sea ice of the Weddell Sea during winter: effects of sea ice texture and algae. Polar Biol. 11: 449-456

Eicken, H., Ackley, S. F., Richter-Menge, J. A., Lange, M. A. (1991). Is the strength of sea ice related to its chlorophyll content? Polar Biol. 11: 347-350

Frankenstein, G., Garner, R. (1967). Equations for determining the brine volume of sea ice from $-0.5^{\circ}$ to $-22.9^{\circ} \mathrm{C}$ Glaciology 6: 943-944

Garrison, D. L. (1991). Antarctic sea ice biota. Am. Zool. 31 $17-33$

Garrison, D. L., Buck, K. R. (1989). The biota of Antarctic pack ice in the Weddell Sea and Antarctica pensinsula regions. Polar Biol. 10: 211-219

Garrison, D. L., Buck, K. R. (1991). Surface-layer sea ice assemblages in Antarctic pack ice during the austral spring: environmental conditions, primary production and community structure. Mar. Ecol. Prog. Ser. 75: 161-172

Garrison, D. L., Close, A. R., Gordon, L. I. (1990). Nutrient concentrations in Antarctic pack ice during winter In Ackley, S. F., Weeks, W. F. (eds.) Sea ice properties and processes. CRREL Monograph 90-1. U.S. Army Corps of Engineers Cold Regions Research \& Engineering Laboratory, Hanover, p. 35-40

Garrison, D. L., Sullivan, C. W., Ackley, S. F. (1986). Sea ice microbial communities in Antarctica. BioSci. 36: 243-250

Glasby, G. P. (1990). Antarctic sector of the Pacific. Elsevier. Amsterdam

Goodman, D. K. (1987). Dinoflagellate cysts in ancient and modern sediments. In: Taylor, F. J. R. (ed.) The biology of dinoflagellates. Blackwell Scientific Publications, Oxford p. $649-722$

Grossi, S. M., Kottmeier, S. T., Sullivan, C. W. (1984). Sea ice microbial communities III. Seasonal abundance of microalgae associated bacteria in McMurdo Sound, Antarctica. Microb. Ecol. 10:231-242

Haas, L. W. (1982). Improved epifluorescence microscopy for observing planktonic microorganisms. Annls lnst océanogr., Paris 58(S): 261-266

Hoshiai, T (1972). Diatom distribution in sea ice near McMurdo station and Syowa Stations. Antarctic J. U.S. 7 : $84-85$

Horner, R. A. (1985). Ecology of sea ice microalgae. In: Horner, R. A. (ed.) Sea ice biota. CRC Press, Boca Raton p. $83-103$

Javor, B. (1989). Hypersaline environments. Springer-Verlag. Berlin

Knox, G. A. (1990). Primary production and consumption in McMurdo Sound, Antarctica. In: Kerry, K. R., Hempel,
G. (eds.) Antarctic ecosystems: ecological change and conservation. Springer-Verlag, Berlin, p. 115-128

Kottmeicr, S. T., Miller, M. A., Lizotte, M. P., Craft, L. L. Sullivan, C.W., Gulliksen, B. (1985). Ecology of sea ice microbial communities during the 1984 winter-to-summer transition in McMurdo Sound, Antarctica. Antarctic J. U.S 20: $128-130$

Kottmeler, S. T., Sullıvan, C. W. (1988). Sea lce Microbial Communsties (SIMCO). 9. Effects of temperature and salınity on rates of metabolism and growth of autotrophs and heterotrophs. Polar Biol. 8: 293-304

Lake, R. A., Lewis, E. L. (1970). Salt rejection by sea ice during growth. J. geophys. Res. 75: 583-597

Lessard. E. (1991). The trophic role of heterotrophic dinoflagellates in diverse marine environments. Mar. microb. Fd Webs 5: 49-58

Lewis, M. R., Cullen, J. J., Platt, T (1983). Phytoplankton and thermal structure in the upper ocean: consequences of nonuniformity in chlorophyll profile. J. geophys. Res. 88 2565-2570

Maykut, G. A. (1985). The ice environment. ln: Horner, R. A (ed.) Sea ice biota. CRC Press, Boca Raton, p. 21-82

Matsuda, O., Ishikawa, S., Kawaguchi, K. (1990). Seasonal variation of particulate organic matter under the Antarctic fast ice and its importance to benthic life. In: Kerry, K. R., Hempel, G. (eds.) Antarctic ecosystems: ecological change and conservation. Springer-Verlag, Berlin, p. $143-148$

McConville, M. J., Wetherbee, R. (1983). The bottom-ice microalgal community from annual ice in the inshore waters of east Antarctica. J. Phycol. 19: 431-439

Meguro, H. (1962). Plankton ice in the Antarctic ocean. (Antarctic Record). Nankyoku Shiryo 14: 72-79

Mitchell, J. G., Silver, M. W. (1982). Modern archaeomonads indicate sea-ice environments. Nature, Lond. 296 437-439

Palmisano, A. C., SooHoo, J. B., Sullivan, C. W. (1987). Effects of four environmental variables on photosynthesis-irradiance relationships in Antarctic sea ice microalgae. Mar Biol. 94: 299-306

Palmisano, A. C., Sullivan, C. W. (1983). Sea Ice Microbial Communities (SIMCO) I. Distribution, abundance, and primary production of ice microalgae in McMurdo Sound. Antarctica in 1980. Polar Biol. 2: 171-177

Parsons, T R., Maita, Y., Lalli, C. M. (1984). A manual of chemical and biological methods for seawater analysis. Pergamon Press, Oxford

Platt, T., Jassby, A. D. (1976). The relationship between photosynthesis and light for natural assemblages of coastal marine phytoplankton. J. Phycol. 12: 421-430

Platt, T., Lewis, M. R., Geider, R. (1984). Thermodynamics of the pelagic ecosystem: elementary closure conditions for biological production in the open ocean. In: Fasham, M. (ed.) Flows of energy and materials in the marine environment. Plenum, New York, p. $49-84$

Putt, M., Stoecker, D. K. (1989). An experimentally determined carbon:volume ratio for marine 'oligotrichous' ciliates from estuarine and coastal waters. Lımnol. Oceanogr. 34: $1097-1103$

Sasaki, H., Watanabe, K. (1984). Underwater observations of ice algae in Lutzow-Holm Bay, Antarctica. Antarctic Rec. $811-8$

Silver, M. W., Mitchell, J. G., Ringo, D. L. (1980). Silceous nanoplankton. II. rowly discovered cysts and abundant choanoflagellates from the Weddell Sea, Antarctica. Mar. Biol. 58: 211-217 
SooHoo, J B., Palmisano, A. C., Kottmeier, S. T., Lizotte, M. P., SooHoo, S. L., Sullivan, C. W. (1987). Spectral light absorption and quantum yield of photosynthesis in sea ice microalgae and a bloom of Phaeocystis pouchetii from McMurdo Sound, Antarctica. Mar Ecol. Prog. Ser. 39: $175-189$

Stoecker, D. K., Buck, K. R, Putt, M. (1991). Photosynthetic dinoflagellates and their cysts characteristic of the landfast ice. Antarctic J. U.S. (in press)

Stoecker, D. K., Buck, K. R., Putt, M. (1990). A flagellate and ciliate dominated microbial community in the land-fast ice. Antarctic J. U.S. 25: 197-199

Stoecker, D. K., Taniguchi, A., Michaels, A. E. (1989). Abundance of autotrophic mixotrophic and heterotrophic planktonic ciliates in shelf and slope waters. Mar. Ecol. Prog. Ser. 50: 241-254

Takahashi, E., Watanabe, K., Satoh, H. (1986). Siliceous cysts from Kita-No-Seto Strait, north of Syowa Station, Antarctica. Mem. natn. Inst. Polar Res., Tokyo, Spec. Issue 40: $84-95$

This artıcle was submitted to the editor
Thomsen, H. A., Buck, K. R., Bolt, P. A., Garrison, D. L. (1991) Fine structure and biology of Cryothecomonas gen. nov (Protista incertae sedis) from the ice biota. Can. J. Zool. 69 1048-1070

Vincent, W. F. (1988). Microbial ecosystems of Antarctica Cambridge University Press, New York

Watanabe, K., Satoh, H., Hoshiai, T. (1990). Seasonal variation in ice algal assemblages in the fast ice near Syowa Station in 1983/84. In: Kerry, K. R., Hempel, G. (eds.) Antarctic ecosystems: ecological change and conservation. Springer-Verlag, Berlin, p. 136-142

Weeks, W. F. Ackley, S. F. (1982). The growth, structure and properties of sea ice. CRREL Monograph 82-1, U. S. Army Corps of Engineers, Cold Regions Research \& Engineering Laboratory, Hanover

Wright, S. W. Burton, H. R. (1981). The biology of Antarctic saline lakes. Hydrobiologia 82: 319-338

Zwally, H. J., Parkinson, C. L., Comiso, J. C. (1983). Variability of Antarctic sea ice and changes in carbon dioxide. Science 220: 1005-1012

Manuscript first received: February 12, 1992

Revised version accepted: June 17, 1992 